TECHNICAL SCIENCES AND TECHNOLOGIES

UDC 621.865.8:007.52

DOI: $10.25140 / 2411-5363-2019-4(18)-49-54$

\author{
Jan Semjon, Martin Kocan
}

\title{
PROPOSAL OF ROBOTIZED CELL WITH ROBOT KUKA KR 6 FOR EDUCATIONAL PURPOSES
}

Urgency of the research. The issue of using robotic workplaces for training students of technical fields is highly topical. It makes it possible to increase the labour market participation of students not only for the needs of the present, but also for the future. The design and implementation of an educational robotized workplace make it possible to prepare students according to their needs and current knowledge.

Target setting. The aim of the solution is to design an educational workplace for handling, equipped with a Kuka KR6 robot and pneumatic effector. The three-finger effector from SMC allows you to hold and carry objects with a maximum clamping force of $130 \mathrm{~N}$. At the same time, the workplace allows you to place handling objects in a total of 32 positions.

Actual scientific researches and issues analysis. The deployment of angular industrial robots has also penetrated into other areas of industry where their use was only sporadic. This creates the need for additional personnel able to program the robot and set the technology for a specific issue of the robotized workplace.

Uninvestigated parts of general matters defining. Improvement of students' knowledge or retraining of employees creates preconditions for their better application in technical practice. The ability to realize customized programs on industrial robots currently deployed in industry prepares students to perform their work without the need for further training, saving costs and time for employers.

The research objective. The aim of the research was to design an educational robotized workplace in order to prepare students according to the specific needs of employers. The workplace allows the use of other pneumatic grippers, while it is possible to connect a total of 16 inputs and outputs for the use of other peripheral devices. The robot can also be used to create a program in an ROS environment, which in turn creates the need to use a Kinect device to detect not oriented components.

The statement of basic materials. The use of the robot, whose control system KR C4 is one of the most modern, allows students to prepare for the needs of practice in the nearest future. After completing the training, the student is able to program on-line Kuka robots for industrial use.

Conclusions. The article focuses on the design and creation of a training robotized workplace for creating programs using a pneumatic gripper. The design and use of the chessboard makes it possible to create a large number of possible combinations for training purposes. This creates a good precondition for adapting training to the specific needs of trained groups. The use of horizontal and inclined plane will teach students how to use the co-ordinate system of the tool or external base when programming. For this reason, programming the movement of the robot along the correct trajectory is more complex and improves the spatial perception of the students in the robot workspace.

Keywords: industrial robot; Kuka; chessboard; manipulation.

Fig.: 6. Table: 1. References: 9 .

Problem definition. The deployment of industrial robots in various industries has an increasing trend related to the need for human replacement in the production process. The increasing cost of human wages, as well as the lack of a skilled workforce, force manufacturing plants to robotized work tasks. Especially those operations that do not require human creativity. The deployment of a qualified worker moves to the position of supervisor of a possible programmer, who keeps the operation within the required limits. This creates the need to find enough workers in the labour market to be able to revive, operate and carry out the necessary maintenance of industrial robots. Colleges and universities must therefore prepare students so that they are able to accomplish these tasks when they enter the labour market $[1,2]$.

Continuous development in the field of technology improvement (welding, spraying, joining materials, etc.), used as end effectors on industrial robots complicates the preparation of students for a specific application. Therefore, it is important that students have a broader view in this area and understand the processes that lead to successful programming not only of the robot trajectory, but also of the setting of the end effector parameters. The ability to create programs for industrial robots from various manufacturers creates good conditions for the student's position in the labour market not only in Slovakia but also in other developed countries [3, 4].

The KR 6 R900 sixx is a compact six-axis robot designed for the highest working speeds. Different designs, mounting positions, reaches and loads make this little robot a good teaching aid. The robot is characterized by its versatility, which allows the use of in new areas of application. Regardless of whether it is on the floor, ceiling or wall - thanks to the integrated power supply and proven control, the KR C4 compact delivers the highest precision in the

(c) Семйон Ян, Кочан Мартін, 2019 
TECHNICAL SCIENCES AND TECHNOLOGIES

smallest space. The new automation concepts enable the Safe-Robot function and are available in cleanroom, explosion-proof, hygienic design or splash-proof versions $[5,6]$.

Base parameters robot KUKA KR 6 are shown in Table 1.

Table 1

Kuka robot parameters [7]

\begin{tabular}{|l|c|}
\hline Weight & $52 \mathrm{~kg}$ \\
\hline Maximum load capacity & $6 \mathrm{~kg}$ \\
\hline Rated load capacity & $3 \mathrm{~kg}$ \\
\hline Workspace radius & $901 \mathrm{~mm}$ \\
\hline Speed & $300-615^{\circ} / \mathrm{s}$ \\
\hline Repeatability & $+/-0.03 \mathrm{~mm}$ \\
\hline Power supply & $230 \mathrm{~V}, 50 \mathrm{~Hz} / 2.5 \mathrm{kVA}$ \\
\hline
\end{tabular}

Current status in workplace. The workplace is created especially for the needs of teaching and training according to the requirements of the project "Starting package of investment elements for lifelong learning at TUKE". This is a special preparation of TUKE graduates for the needs of companies working in the deployment of robotized lines in the automotive industry, especially for VW and Daimler. The KUKA KR 6 industrial robot with the KR C4 Compact control system, the work table and the pneumatic gripper SMC MHS3 40D are located at the workplace (fig. 1).

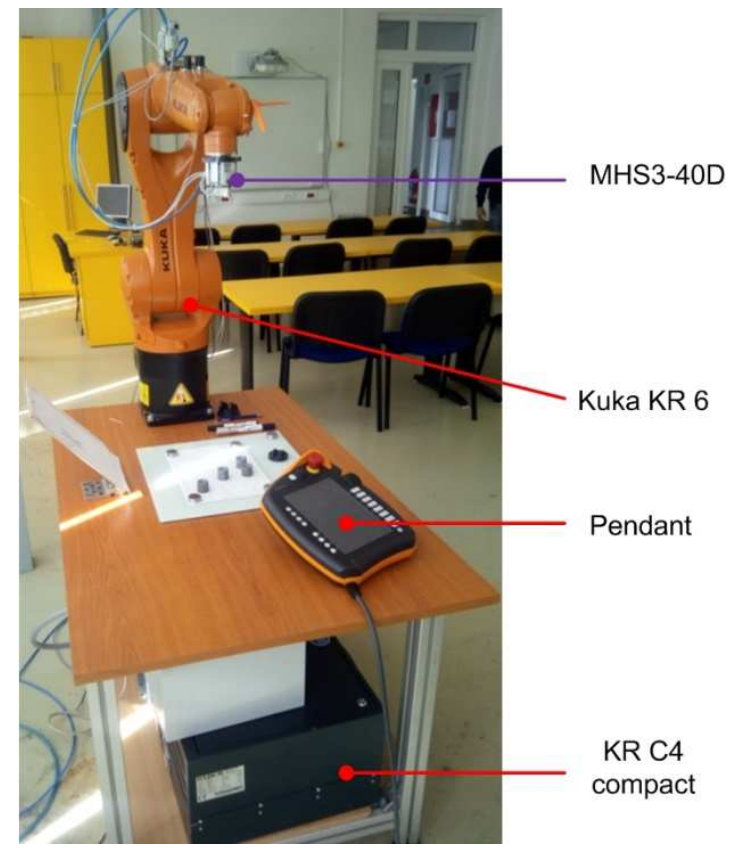

Fig. 1. Robotized workplace

The latest generation of $\mathrm{C} 4$ control systems is available in five versions. Physically the smallest type is the C4 Compact, which has dimensions of $271 \times 483 \times 460 \mathrm{~mm}$. It includes an SSD for faster response, can control 6 axes and 2 additional axes as an option. The weight of the unit is $33 \mathrm{~kg}$ and the ambient temperature in which it can operate is 5 to $45^{\circ} \mathrm{C}$. The interface used by the unit is USB 3.0, GbE and DVI-D and Display Port.

The pneumatic three-finger gripper MHS3 - 40D from SMC is characterized by the used cylinder of size series 40 , fig. 2 . The stroke of the double-action gripper is $8 \mathrm{~mm}$. The clamping force is $118 \mathrm{~N}$ for gripping the outer surface of the object and $130 \mathrm{~N}$ for gripping the inner surface of the handling object. The weight of the fingerless gripper is $351 \mathrm{~g}$. The repeatability of the gripper can be up to $\pm 0.01 \mathrm{~mm}$. The gripper is fitted with a pair of end magnetic sensors to monitor the opening and closing of the fingers. The SY5120-5Y0-01F-0 valve from $\mathrm{SMC}$ is used to control the gripper $[8,9]$. 
TECHNICAL SCIENCES AND TECHNOLOGIES
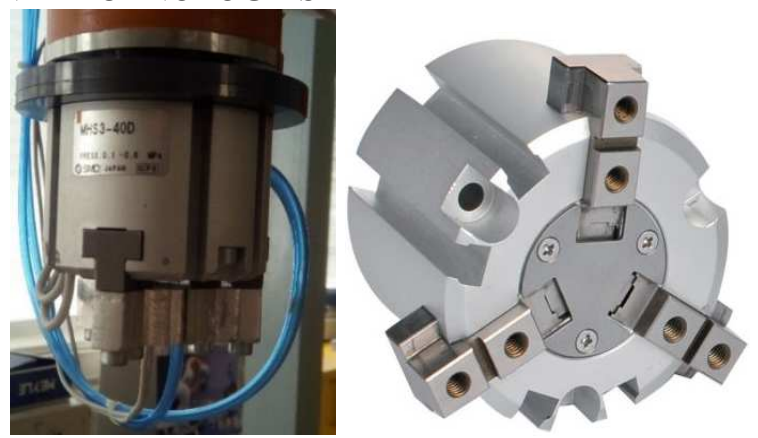

Fig. 2. Pneumatic gripper SMC

The proposed work scenario focuses on the handling process. The task of the students at the workplace will be to translate metal pipes of Ø26x2 - $25 \mathrm{~mm}$ (fig. 3) from designated positions to positions given by the teacher.

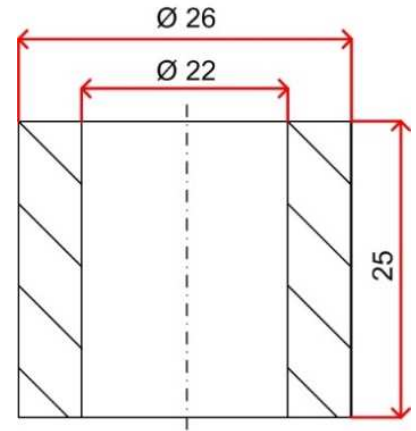

Fig. 3. Object of manipulation

Proposal of robotized workplace. The removal or storage location is located in the robot's workspace at the base of the robot or on an inclined plane. The usable working area on the table where the robot is located is $600 \times 600 \mathrm{~mm}$. The inclined plane is $300 \times 300 \mathrm{~mm}$ and allows you to adjust the tilt angle from 0 to $90^{\circ}$. The inclined plane includes a layer where four $60 \mathrm{~mm}$ magnetic strips are placed. The tapes are located below the chessboard area where students store the manipulation objects to ensure they are retained when the gripper opens.

In the work area is placed "checkerboard" External dimension of 300 x $300 \mathrm{~mm}$ in (fig. 4). The chessboard contains $16(4 \times 4)$ positions where manipulation objects can be stored. It is marked on the horizontal axis with numbers 1 to 4 and on the vertical axis with letters A to D. The diameter of the marked area is $27 \mathrm{~mm}$, which allows to store the manipulation object with a tolerance of $\pm 0.5 \mathrm{~mm}$.

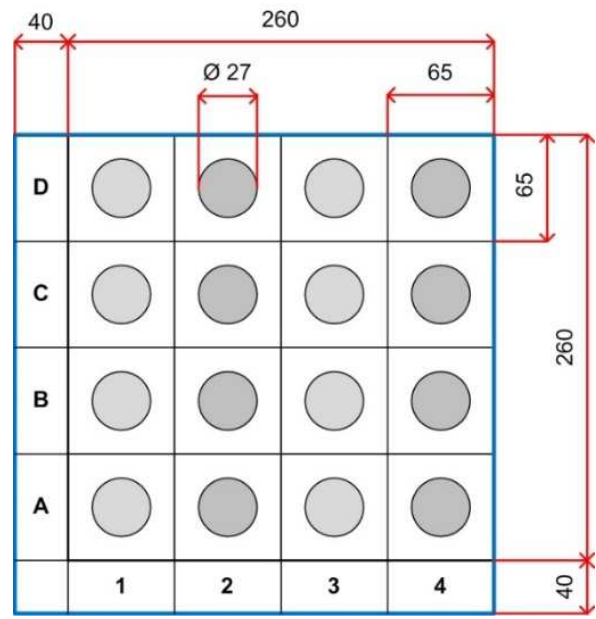

Fig. 4. Chessboard no. 1 
TECHNICAL SCIENCES AND TECHNOLOGIES

When entering individual assignments by students, it is possible to choose different combinations. Most often, students are required to remove and transship 4 pieces of handling objects. If students have minimal experience in robot programming, a configuration is used where they remove and translate manipulation objects only on a horizontally placed chessboard. In (fig.5) is a view of the workplace where from the chessboard No. 1 (positions A1 and $\mathrm{C} 4$ ) it is necessary to move the manipulation objects to the chessboard No. 2. Location to store is $(\mathrm{C} 1$ and $\mathrm{A} 3)$. The other two manipulation objects need to be moved from the chessboard no. 2 (D1 and B4) on chessboard no. 1 (A4 and D1).

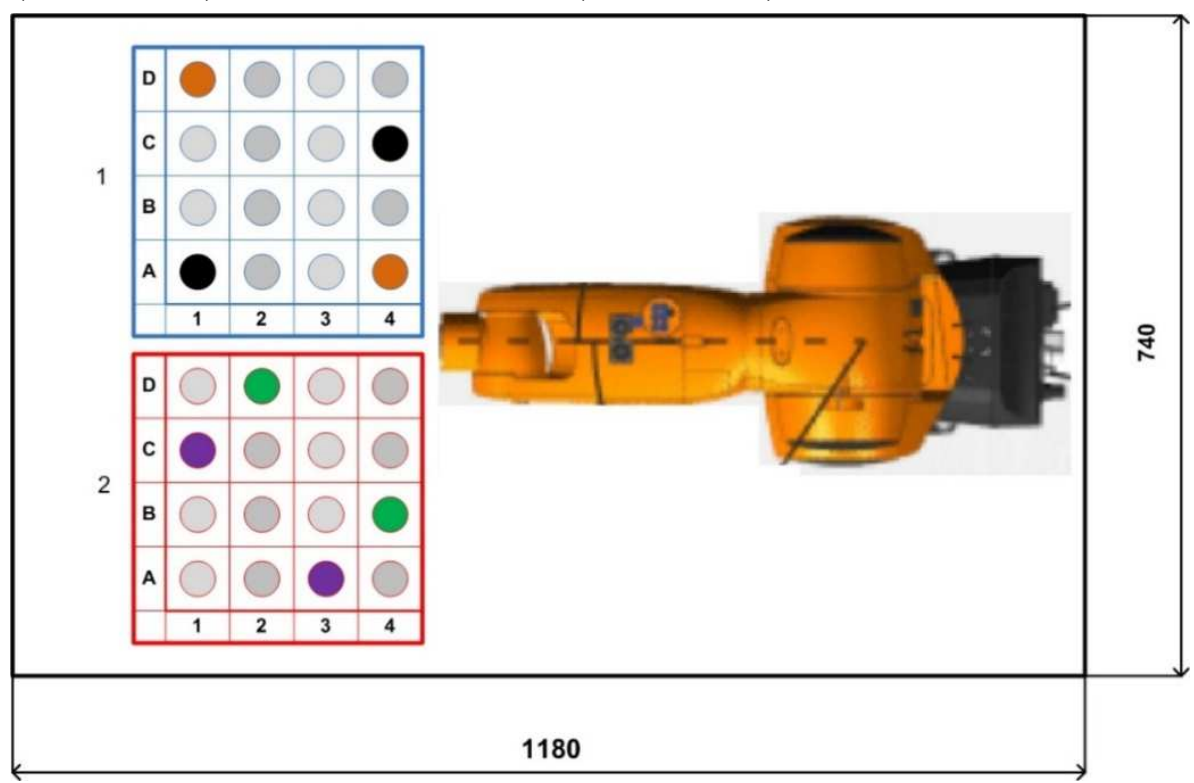

Fig. 5. Horizontal placement of two chessboards

Students with more experience in robot programming remove and store manipulation objects from a horizontal chessboard to an inclined chessboard. That is, they remove two manipulation objects from a chessboard located on an inclined plane to a chessboard mounted on a horizontal plane. At the same time, the other two manipulation objects translate from the horizontal chessboard to a chessboard mounted on an inclined plane, FIG. 6. An example of an assignment for a student can be as follows: translate manipulation objects from chessboard no. 1 ( $\mathrm{C} 1$ and $\mathrm{B} 3$ ) to chessboard no. 2 (D2 and B4). Then translate the manipulation objects from chessboard no. 2 (B1 and D4) to chessboard no. 1 (A2 and $\mathrm{C} 2$ ).

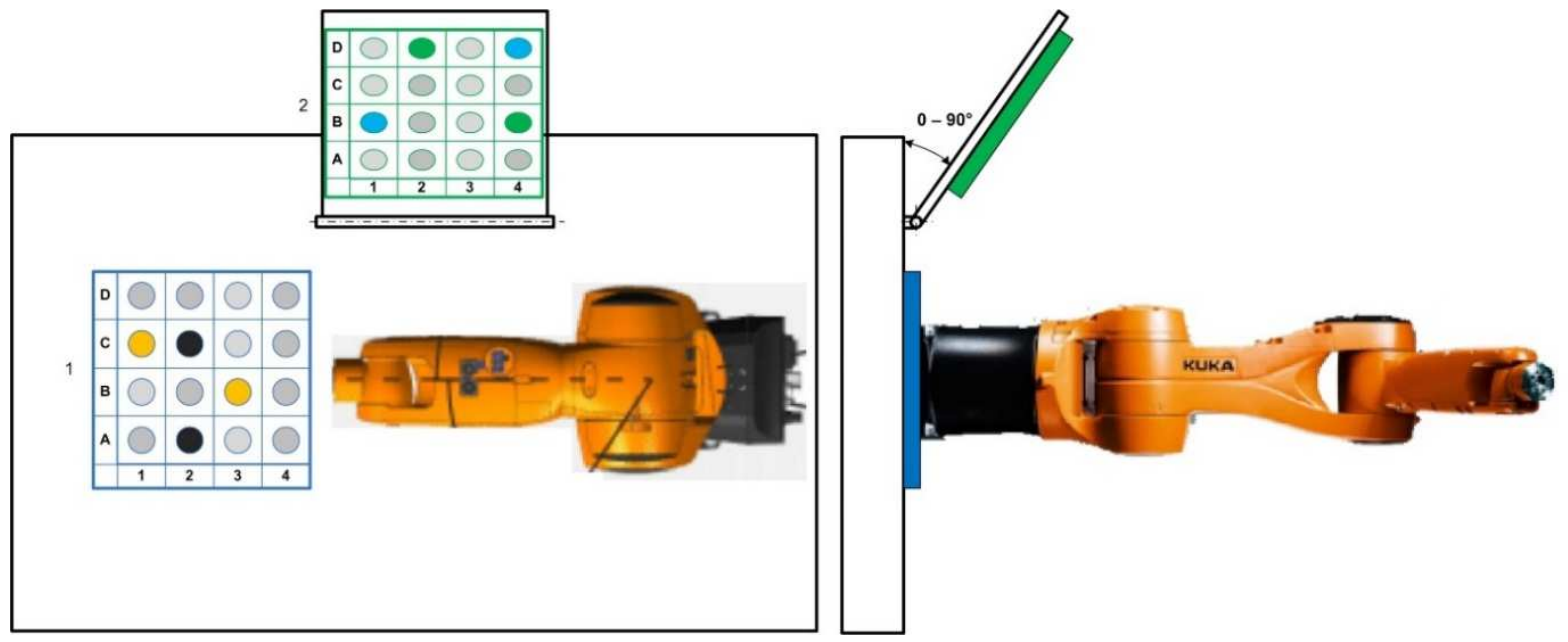

Fig. 6. Chessboard placed horizontally and on an inclined plane 
TECHNICAL SCIENCES AND TECHNOLOGIES

Since we have 32 (2x16) possible positions for taking and storing manipulation objects, there are a large number of possible combinations. This allows the teacher to customize the number of objects and the location of manipulation objects according to the individual needs of a particular student. The student's task is not only to program the robot trajectory, but also to be able to work with digital inputs and outputs. Using them, the student can control the closing and opening of the gripper in positions where individual objects of manipulation are taken and stored.

Conclusions. Creating a robotized workplace enabling students to improve their competences will ensure their better employment in the labor market. The possibility to create various configurations from the used chessboards allows the teacher to customize the assignment according to the needs or knowledge of a particular student. Placing the chessboard on an inclined plane improves the student's imagination for programming. To create a trajectory of movement, they use a shift in three perpendicular axes. However, to store or remove the manipulation object from an inclined plane, it is also necessary to use rotation about the respective axis. The use of pneumatic gripper puts demands on students to use inputs and outputs of the robot or logical variables.

Acknowledgement. This publication was supported by project VEGA 1/0389/18: Research and development of kinematic redundant mechanisms.

\section{References}

1. Hajduk, M., Sukop, M., Semjon, J., Janos, R., Varga, J., Vagas, M. (2018). Principles of Formation of Flexible Manufacturing Systems. Tehnicki Vjesnik = Technical Gazette. Vol. 25, no. 3, P. 649-654. ISSN 1330-3651.

2. Hajduk, M., Semjon, J., Varga, J. (2017). Utilization of SCARA robots in the assembly of electrical contacts. International Journal of Mechanical Engineering and Robotics Research. Vol. 6, no. 5. P. 360-365. ISSN 2278-0149.

3. Semjon, J. (2018). Programovanie priemyselných robotov 1, 1. vyd. - Košice: Technická univerzita v Košiciach, 2018. 123 p. ISBN 978-80-553-3283-3. (In Slovak).

4. Semjon, J., Kostka, J., Mako, P. (2019). Using the simulation program for the design and optimization of the production line. Technical Sciences and Technologies. Cernihiv (Ukrajina): Chernihiv National University of Technology. Vol. 13, no. 3. P. 61-67. ISSN 2411-5363.

5. Kuka Deutschland GmbH: Pub Spez KR AGILUS sixx (PDF) en PB391/ Spez KR AGILUS sixx V14, Issued: 08.10.2018.

6. Kuka. Retrieved from http://www.automatechrobotik.com/docs/Kuka\%20Agilus.pdf.

7. Kuka. Retrieved from https://www.robots.com/robots/kuka-kr-6-r900-sixx.

8. SMC. Retrieved from https://content.smcetech.com/pdf/MHS3_3126.pdf.

9. SMC. Retrieved from https://www.smc.eu/portal_ssl/WebContent/local/DK/.

УДК 621.865.8:007.52

Ян Семйон, Мартін Кочан

\section{ПРОПОЗИЦІЯ РОБОТИЗОВАНОГО РОБОЧОГО МІСЦЯ 3 РОБОТОМ КUКА КR 6 ДЛЯ НАВЧАЛЬНИХ ЦІЛЙ}

\footnotetext{
Актуальність теми дослідження. Питання використання роботизованих робочих місиь для навчання студентів технічних галузей є надзвичайно актуальним. Це дає змогу збільиити зайнятість студентів на ринку праці не лиме для потреб сьогодення, але й для майбутнього. Розробка та реалізація навчального робототехнічного робочого місия дають можливість готувати студентів відповідно до їх потреб та сучасних знань.

Постановка проблеми. Мета рішення - розробити навчальне робоче місие для обробки, обладнане роботом Kuka KR6 та пневматичним ефектором. Ефектор з трьома пальиями SМС дозволяє утримувати та переносити предмети з максимальним зусиллям затиску 130 Н. В той же час робоче місце дозволяє розмішувати оброблювані об'єкти в загальній кількості на 32 позичіях.

Аналіз досліджень і публікацій. Використання кутових промислових роботів поширилося $і$ в інші галузі промисловості, де їх використовували лише час від часу. Це створює потребу в додатковому персоналі, здатному програмувати робота і налаштувати технологію для конкретної проблеми роботизованого робочого місия.

Виділення недосліджених частин загальної проблеми. Покращення знань студентів або перепідготовка працівників створює передумови для їх кращого застосування в технічній практиці. Можливість реалізувати спеціалізовані програми на роботах промислового рівня готує студентів виконувати свою роботу без необхідності додаткового навчання, економлячи витрати та час для роботодавців.
} 
TECHNICAL SCIENCES AND TECHNOLOGIES

Постановка завдання. Метою дослідження було розробити навчальне робототехнічне робоче місие з метою підготовки студентів відповідно до конкретних потреб роботодавиів. Робоче місие дозволяє використовувати інщі пневматичні захоплювачі, також можливо підключити загалом до 16 входів і виходів для з'єднання з іншими периферійними пристроями. Робот також може використовуватися для створення програми в середовищі ROS, що, в свою чергу, створює необхідність використання пристрою Кіпесt для виявлення неорієнтованих компонентів.

Виклад основного матеріалу. Використання робота, чия система управління KR C4 є однією з найсучасніших, дозволяс студентам підготуватися до потреб практики в найближчому майбутньому. Після закінчення навчання студент може програмувати он-лайн роботи Киkа для промислового використання.

Висновки відповідно до статmі. Стаття висвітлює розробку та створення навчального роботизованого робочого місия для створення програм з використанням пневматичного захвату. Конструкція та використання шахової дошки дає можливість створити велику кількість можливих комбінацій для навчальних иілей. Це створює хорошу передумову для адаптачіï навчання до конкретних потреб групп, щзо навчаються. Використання горизонтальної та похилої площини навчить учнів використовувати систему координат інструменту або зовнішньої бази при програмуванні. 3 иієї причини програмування руху робота по правильній траєкторії є більш складним і покрашує просторове сприйняття учнями робочої області робота.

Ключові слова: робот; програмування; навчання; логотип.

Рис.: 6. Табл.: 1. Бібл.: 9.

Semjon Jan - Associate Professor, PhD of technical sciences, Faculty of Mechanical Engineering, Department of Robotics, Technical University of Kosice (Park Komenskeho 8, 04200 Kosice, Slovak Republic).

Семйон Ян - доцент, кандидат технічних наук, механічний факультет, кафедра робототехніки, Технічний університет Кошице (Park Komenskeho 8, 04200 Kosice, Slovak Republic).

E-mail: jan.semjon@tuke.sk

SCOPUS Author ID: 55571411200

Martin Kočan - PhD student, Faculty of Mechanical Engineering, Department of Robotics, Technical University of Kosice (Park Komenskeho 8, 04200 Kosice, Slovak Republic).

Кочан Мартін - аспірант, механічний факультет, кафедра робототехніки, Технічний університет Кошице (Park Komenskeho 8, 04200 Kosice, Slovak Republic).

E-mail: martin.kocan.student@tuke.sk 